\title{
The Complexities of Biblical Typology in the Seventeenth Century
}

\author{
DONALD R. DICKSON
}

The last decade has seen a resurgence of interest in biblical typology among scholars of seventeenth-century literature. Early studies by William Madsen, Murray Roston, and Barbara Lewalski paved the way for the broader application offered by Earl Miner's collection of essays, Literary Uses of Typology, and Lewalski's Protestant Poetics. ${ }^{1}$ This renewed interest in typology, however, has led some critics to a reductive paradigm to account for the use of figurative language in the seventeenth-century devotional literature: since one image prefigured another more perfect manifestation of that image, all one had to do was simply match types with their corresponding antitypes. By recognizing that much of this figurative language was governed by a simple paradigm of promise and fulfillment, scholars were hoping to respect the religious sensibilities of those Renaissance poets and theologians who had rejected the medieval fourfold allegory that had turned the literal text of Scripture into a hidden veil pointing to a meaning beyond itself. Though seventeenth-century Protestants valued the literal text above all, their actual practices show that they regarded the Bible as a complex text, the full significance of which could only be recovered by means of a sophisticated reading act. By examining some of the many Protestant guides to godliness and other "helps" designed to open Scripture up to its readers, we shall see that Protestants continued to read the Bible - and especially to identify biblical types - using a methodology and a vocabulary not so unlike the approach they had sought to replace. Thus, there is more continuity with medieval hermeneutics than has generally been acknowledged by those who advocate a distinctly "Protestant poetics"; accordingly, the typological wit of Protestant devotional poets may be more complex than has been recognized.

Perhaps the greatest advance offered by the work of Lewalski has been to establish a methodology familiar to modern readers for interpreting devotional poetry. Her approach is to view the Bible as a unified poetic text requiring close reading to recover its full meaning (and in this, her work in indebted to Northrup Frye's). Since seventeenth-century readers saw 
Scripture "as a complex literary work whose full literal meaning is revealed only by careful attention to its poetic texture and to its pervasive symbolic mode - typology," the Bible also provided its own hermeneutic key through the collation of one text with another to recover its meaning. ${ }^{2}$ Biblical typology is being increasingly regarded as a method of decoding, or more properly as a set of reading practices, which determined largely the way many seventeenth-century readers perceived the organizing structures (both narrative and metaphoric) of the Bible. Though much has been written of late on typology in the Renaissance, ${ }^{3}$ little attention has been given to the rather systematic rules that seventeenth-century Protestants were offered. By examining typology as a formal method of decoding a text, weshall see that, as it became increasingly recognized as the fundamental symbolic mode of the Bible, the reformers began to use biblical typology in a more complex way than simply matching. Old Testament types with New Testament antitypes. The typological explications commonly available in the seventeenth century linked the history and drama of Christ's life (as foreshadowed and then fulfilled in the two testaments) with the salvation drama of each believer and with the whole span of sacred history. The Bible was seen as telling one essential story, Christ's; but, through his story, the history of the creation, fall, redemption, and glorification of both man and the universe was told typologically. It is necessary to recognize, therefore, in addition to the familiar Christological types (which do depend on a simple type and antitype relationship), sacramental types - through which the individual's salvation history is told in imitation of Christ:- and eschatological types - through which the ultimate glorification of Christ, man, and the universe is foreshadowed and fulfilled. The implications of this complex view of typology are especially significant for students of the devotional poetry of the early seventeenth century, since so much of this literature was influenced by and dependent on the way the Bible was read and understood.

When the Bible is approached as a complex text, it obviously requires the rigorous scrutiny of its readers. John Smith, writing about mid-century, stated

I apprehended it a work worthy the understanding, to dig into these sacred Minerals for the better finding out the Metaphors, Metonymies, Synecdoches, \&c. which lie hid there... . For the bare reading of the Scripture, without searching into its heavenly mysteries and meaning, is like the coming into a Treasury, wherein we see many costly things folded up, and some ends appearing out, but when they be all unfolded, then doth their glory more affect us for the present, yea, and leave in us a deep impression of their excellency. ${ }^{4}$ 
Numerous "helps" were available to enable the reader to enrich himself at the biblical treasury. Some were general guides for theological students, young divines, or householders responsible for the religious life of their families and servants; others were specifically exegetical tracts, ranging from works devoted to the explication of individual books - e.g., Ainsworth's Annotations upon Genesis (1616) - to multivolume works on all of Scripture - e.g., Mayer's A Commentary upon the whole of the Old Testament, added to that of the same author upon the whole New Testament (OT, 4 vols., 1653-47; NT, 3 vols., 1631). Most of the general guides offered very similar advice on reading Scripture systematically and prudently.

The English reformers who wrote the most widely-read guidesto Scripture - William Perkins, John Weemes, John White, and Henry Lukin - all accepted as axiomatic the Protestant emphasis on the literal level of the text, scriptura sola, by proclaiming that Scripture rightly studied provided its own key to interpretation. As Perkins stated emphatically, "The supreame and absolute meane of interpretation, is the Scripture it selfe." 5 All agreed that the first step in reading was philological: "words have some determinate signification, else they were of no use, to no purpose; but as a Trumpet giving an uncertain sound, 1 Cor. 14.8. But for their signification, we must have recourse to Use and Custome." ${ }^{6}$ A knowledge of Hebrew and Greek was helpful, but etymology alone.was not sufficient, since meaning or "signification". was dependent in part on context - "that sense, which they have by use obtained."? Studying scriptural "Use and Custom" implicitly established the Bible as a unified whole that permitted, indeed required, diligent comparison of text with text to recover meaning. The reformers were also guided by the collective wisdom of their best theologians. Since God had to accommodate things divine to human understanding, the Bible contained infinitely subtle points that could easily be misunderstood. Readers were urged furthermore to be guided in their interpretations by those principles of faith commonly agreed upon in the tradition of the analogia fidei (derived from Rom. 12:6). ${ }^{8}$

To accomplish their basic goals of using Scripture as its own best key, Perkins, White, Lukin, and others offered a method of reading that began with philological comparisons and advanced to comparisons of one text with another. ${ }^{9}$ Perhaps the most scholarly and systematic methodology can be found in Weemes' Christian Synagogue. He stated that the first task was dittologia, or marginal line reading of the Mazora Bible for use in glossing one line with another. The second task was sigmatologia, or the right pointing of the text (i.e., the vowel points and accents of the Hebrew Text). Once these philological tasks were settled, the third step was analogia, or the collation of one text with another. ${ }^{10}$ All four authors affirmed that collation was the key to perceiving the unity of the whole. As William Perkins explained, "The collation or comparing of places together, is that, 
whereby places are set like parallels one beside another, that the meaning of them may more evidently appeare." 11

The practice of reading Scripture by collating text with text had both historical and biblical precedent, as the reformers well knew. The Hebrews had from an early time divided the Pentateuch into fifty-four weekly lessons, called parashah. When Antiochus Epiphanes came to power in the second century B.C., he forbad the reading of the Mosaic law, so the Jews then chose their readings from those parts of the Prophets "most answerable" to the forbidden parts of the Law, as Weemes explained it. ${ }^{12}$ Once this tradition was established, each reading from the Prophets, or haphtarah, was still read with its parashah even after the tyranny of Antiochus was ended. Thus the Law had been collated with the Prophets in Old Testament times. When the Apostles used the same method of collating text with text "to let us see the harmony andcontent that is betwixt the Old and New Testament," 13 they were following the historical precedents of their forefathers. Furthermore, the authors of the New Testament recognized and noted certain events from the Old Testament - such as the flood, the exodus, the exile, and the return - as foreshadowings of events that would be reiterated and consummated in Christ and his church (see, e.g., 1 Cor.10:1-5). So the practice of collating texts to recover the meaning of the whole had solid scriptural authority, and it provided St. Paul with an important exegetical method - instrumental in forming his conception of Christianity and for that reason very attractive to the reformers - typology.

Typology is so important to the reformers that it has been said to constitute the basic element of the code for reading the Bible in the seventeenth century. The reformers derived the principle from Scripture itself - the epistles of St. Paul - though they had to reshape them for their own ends. The passages in the Pauline epistles containing figural, or typological interpretations, Erich Auerbach explains, were written during Paul's bitter struggle to defend the early Christians:

His whole figural interpretation was subordinated to the basic Pauline theme of grace versus law, faith versus works: the old law is annulled; it is shadow and typos; observance of it has become useless and even harmful since Christ made his sacrifice; a Christian is justified not by works in observance of the law, but by faith; and in its Jewish and Judaistic legal sense the Old Testament is the letter that kills, while the new Christians are servants of the new covenant, of the spirit that gives life. ${ }^{14}$

While St. Paul's revaluation of the Old Testament was indicated by only a few broad strokes, his method and intentions seem clear enough. The 
Old Testament was transformed from the history of the Jews into a universal history in which Christ's coming was foreshadowed by types - the Greek word has the basic meaning of an "imprint" left by a blow, hence an "impression" or "image." But in so doing the Jews were reduced to the status of shadowy types, and hence the Old Testament was reduced to a secondary position theologically since the law had been supplanted by grace.

While Apostolic teaching simply showed that types had been fulfilled in Christ, the early Fathers of the Church incorporated typology into a more complex exegetical method - based also on the Pauline distinction between "letter" and "spirit," law and grace - and began to apply types to eschatology (Irenaeus and Origen) and to the interior life of the Christian (Clement and Ambrose). ${ }^{15}$ Their fourfold exegesis, however, tended to devalue the historical or literal level of the text, for, if "the letter killeth but the spiritgiveth life" ( 2 Cor. $3: 6$ ), then the letter of the text was obviously in an inferior position. Thomas Aquinas provided the theory of signs underlying the medieval hermeneutic developed by Augustine and Hugh of St. Victor that emphasized the spiritual sense of the text. He posited that the words of Scripture, the sensus litteralis, mean one thing only; verba (words) always signify res (things). The sensus spiritualis, however, derives not from the words but from the relationship of one referent $\left(\right.$ res $\left.^{1}\right)$ with other referents $\left(\right.$ res $\left.^{2}\right) .{ }^{16}$ In his Summa Theologica, Aquinas explained:

That God is the author of holy Scripture should be acknowledged, and he has the power, not only of adapting words to convey meanings (which men can do), but also of adapting things themselves. In every branch of knowledge words have meaning, but what is special here [in Scripture] is that the things meant by the words also themselves mean something. That first meaning whereby the words signify things belongs to the sense firstmentioned, namely the historical or literal. That meaning, however, whereby the things signified by the words in their turn also signify other things is called the spiritual sense; it is based on and presupposes the literal sense. Now this spiritual sense is divided into three.... Well then, the allegorical sense is brought into play when the things of the Old Law signify the things of the New Law; the moral sense when the things done in Christ and in those who prefigured him are signs of what we should carry out; and in the anagogical sense when the things that lie ahead in eternal glory are signified. ${ }^{17}$

In practice the Old Testament was treated as a book of hidden mysteries that had to be unveiled; taken to the extreme, an exegete such as Philo could find symbolic meaning in every detail, however small it might have been. According to H.A. Wolfson, Philo "compares the "mere letter of Scriptures' to 'shadows $(\sigma \kappa \downarrow \propto \sigma)$ ) of bodies' and 'the meanings which are apparent to investigation beneath them' to 'things which truly exist.'" 18 
Philo thus encouraged the reader to discover the hidden, allegorical meaning of the text, which corresponded to the incorporeal mind of the Logos. The literal level of the text thereby came to exist only as a signifier of one of the threefold spiritual levels. Though this method of exegesis had been widely accepted for over a thousand years, the Protestant reformers were troubled by the fact that such allegorical interpretations freqeuntly bore little relationship to the literal text, the revealed Word.

The twin pillars of the reformers' world-view, as well as for their hermeneutic, were scriptura sola - the Word itself as sole authority, which provided its own key to understanding the mysteries of the Christian faith and sola fides - justification by faith (which also gave believers the confidence they could interpret Scripture rightly). Where medieval exegetes had ignored verba andeven res for res ${ }^{2}$ (the hidden thing signified in the text), Protestants insisted that any figurative meaning was a dimension of the literal text - not a distinct sensus spiritualis. Furthermore, as J.S. Preus has argued, Luther no longer saw the antithesis between letter and spirit dividing the testaments, but rather he saw it between the law and its promise. According to medieval exegetes, the faithful Israelites were merely signs foreshadowing Christians since they were sub lege, without grace, and therefore carnal. Not that their story was unimportant, rather their existence under the old law made their experience distinctly different from the one made possible by the true church. Luther, on the other hand, saw their situation in just the same terms as he saw his own: they lived under the same promissio that Christians always will until the second coming. Hence, the faithful Israelites were just as capable of faith in God's covenant as any Christian could be. In affirming that the literal, historical level of the Old Testament had great theological value for the present, Luther prepared the way for later Protestant theologians who would insist on a hermeneutic that would accord full theological value to the entire literal text itself. ${ }^{19}$

Though all authority was said to rest in a literal interpretation of the text, obviously for certain passages the literal meaning had to be also figu rative - as when Christ proclaims he is the true vine (John 15:1). Yet the reformers would not accept that any text could have more than one meaning. Though the literal level of the text often pointed beyond itself to a symbolic meaning, the key still resided in and was controlled by the literal meaning. As John Weemes wrote:

Yet it will not hence follow, that the words of Scripture have two senses, or given an uncertain sound, (to allude to that, 1 Cor. 14.8) The words have one determinate signification, but the things themselves, which the words do properly and literally signifie, do import yet something else. ${ }^{20}$

This "something else" was usually adduced as the type or the antitype. 
Weemes instructed his many readers that the sense of Scripture is simple (i.e., literal) or compound: "A compound sense, is that whereof there are two parts, literall and figurative, to make up one sense, which is fulfilled two manner of wayes, Historice and Prophetice in the type, and literally in the thing signified." 21 Typology thus became a way to recover the symbolic dimension of the Bible, and it was particularly acceptable to the reformers because it could be rigorously, even scrupulously applied - unlike the arbitrary allegorizing of the Fathers. Not only was typology divinely sanctioned (even Christ himself practices it, e.g., Luke 4:21), it also was closely connected with the literal text of the revealed Word. Typology, as it was elaborated in sermons and tracts, established a spiritual relation between two historically real events, such as the flood and baptism. The mistake of the Gothic monkish allegorists, in the view of the reformers, had been toremove the sign from its historical context in the literal narrative of Scripture, which had led to unlimited semiosis: any sign could have any number of referents, unless there was a way to predict or control the process of signification. The historicity of types gave an evidential value to Protestant hermeneutics that allegory did not have. That the type foreshadowed the antitype, which in turn illuminated the meaning of the type, in no way impinged on the absolute historicity of each as events recorded in the Bible. Thus typology came to occupy an important place in the hermeneutics of Luther and an even more central one for Calvin and Erasmus. ${ }^{22}$

Those few who dealt systematically with the thorny problems of the complex language of the Bible - under the influence of Augustine and Aquinas -argued that typology was mainly concerned with things (i.e., events) rather than with signs. Even so they acknowledged that God resorted to metaphor, which advances understanding by denoting a concept using a concrete referent, in order to accommodate divine things to human abilities. ${ }^{23}$ They agreed further that metaphors ought to be interpreted by considering the literal level before the spiritual, ${ }^{24}$ thereby subjecting metaphor to the same rigid controls to which typology was subject. But, though the typologists usually tried to deal with types and antitypes as things or events, their explications show that the images and metaphors that render those events, as signs, were inseparable from their understanding of them. Thus the river of living waters (Rev. 22:1) may not be an actual river as we know it here on earth; nonetheless, as a sign it existed in some relationship with all other signifiers of this thing - whether with the prototypic fountain in Eden, with any of its many Old Testament types (e.g., Ezek. 47:1), or with its New Testament antitypes (e.g., John 4:14). The end result of this understanding of the complexities of the language of Scripture and of the relation of the Old Testament as foreshadowing promises to be fulfilled in the New is that the Bible became a very complex text that required collation of both signifier and signified with other signs to recover its full meaning. 
Typology became so important to Protestant hermeneutics that second and third generation reformers constructed fairly elaborate rules for reading Scripture typologically; there existed, in other words, what critics would now designate as a reading code. Understanding the complexities of this code is obviously important for students of the devotional literature of the age since its poets frequently depended on the Bible for inspiration and models. There were three fundamental principles that all the typological handbooks and guides seemed to agree upon. The first - and perhaps the most important for legitimizing typology as a mode of analysis - is that both types and antitypes involve historically real persons or events. ${ }^{25}$ The second is that the type foreshadowed or prophesied some event that would occur in the New Testament - that is, the imperfect order of the law prepared for the more perfect order of grace. As one typologist wrote, God in the nonage of the church "appointed diverse types and ceremonies, as rudiments and introductions [Gal.4:3], fitted to the grosse and weake sences of that Church, which was brought on by little and little, through such shadows and figures, to the true Image and thing signified." 26 The last major principle is based on St. Paul's understanding of the relationship of the testaments; seventeenthcentury Protestants thus believed they were basing their hermeneutics on the solid foundation St. Paul had provided: the antitype represents a fulfillment of the type, or as Auerbach terms it, the forma perfectior. Christ himself sanctions this key point in Matthew 5:17: "Think not that I am come to destroy the law, or the prophets: I am not come to destroy, but to fulfil."

Aside from these general theoretical principles, the typologists offered rather formal rules for identifying and expounding types. The source for most of the systematic typological studies published in England during the Renaissance was the Philologia Sacra of Salomon Glass (Jena, 1623-1626). Popular works, such as William Guild's Moses Unvailed (1620), Thomas Taylor's Christ Revealed; or, the Old Testament explained (1635), Samuel Mather's The Figures or Types of the Old Testament (1683), and Thomas Worden's The Types unveiled (1664), presented general readers with detailed lists of types. Benjamin Keach, whose monumental Tropologia: A Key to Open Scripture Metaphors (1682) became the English sourcebook for typology, simply translated large portions of the Philologia Sacra. ${ }^{27}$ Keach made available to a wider audience the rules for expounding types that Glass had earlier codified and that Guild and the others followed. Keach's nine canons can be summarized as follows:

1. Whenever an Old Testament text treats of God's grace, propitiation, redemption, or the destruction of his enemies, and a New Testament text sheds light upon it, that text may be expounded as a type. 
2. The type is not necessarily replicated exactly in the antitype, though the antitype will be in some way similar "according to the Habit and Lineament." This is especially true of men who foreshadow Christ since none can be as perfect.

3. Since the antitype fulfills the type, it will contain more of the truth - just as Christ is greater than any who foreshadow him.

4. A "fit Application" of the type to the antitype must hold, according to the Analogy of Faith. That is, the relationships adduced between type and antitype cannot violate other principles of faith.

5. Where many types prefigure a single antitype, onemust consider all the types together. [This means in effect that one must search Scripture well to recover the larger patterns that typology reveals.]

6. Some prophecies of the Messiah in the Old Testament are not veiled as types, but signify the antitype-Christ - literally.

7. The wicked cannot be types of Christ - as, e.g. some would make Absolom hanging by the hair in an oak tree a type of Christ on the cross.

8. One type can foreshadow two diverse things, as the flood is a type of baptism for the faithful and also of the damnation of the reprobate.

9. Sometimes the sign of the type is substituted for that of the antitype and vice versa - e.g., the New Testament church is often called Sion or Jerusalem since these foreshadowed it. ${ }^{2} 8$

Keach's rules for expounding types are based on the theoretical principles discussed above: connection must always be made with literal events; the type foreshadows its antitype; and the antitype is the fulfillment of promises made earlier.

The one significant matter that the typologists apparently did not agree upon was how to distinguish kinds of types. At issue is whether types are strictly Christological and strictly limited to those few mentioned explicitly, or whether typology is more encompassing. Only a few interpreters insisted that every type had been identified as such in the Bible. ${ }^{29}$ Keach was perhaps more representative in distinguishing between innate types (those that Scripture specifically designates) and inferred (those identified by other interpreters).$^{30}$ In addition, he also differentiated, somewhat idiosyncratically, between "prophetical" types and "historical" types, the former involving the actions, dreams, and visions of the prophets and the latter everything else in the Old Testament that adumbrates the New. ${ }^{31}$

Keach's distinctions for the kinds of types have little or no theological backing and represent the only real break he made with his major source, 
Glass. The Philologia Sacra mentioned several other ways of categorizing types (Keach simply neglected to translate them). Glass began his section on the division of types by offering the definition of types made by Junilius, author of an early introduction to the exegesis of Scripture (c. 550), which distinguished types according to time: "quod sit praesentium aut praeteritarum aut futurarum rerum ignotarum, per opera, secundum id, quod opera sunt, manifestatio." 32 To this division according to past, present, and future, he added his own which distinguishedamong types as literal things, types as acts, and types as sacraments (in the original Christian sense of the word which rendered the Greek, any ritual observance or spiritually symbolic act). The first simply matches literal, historical things which bear an obvious similarity: "Typum historiae vocant, qui simpliciter ex re ista desumitur" (they refer to the type of the literal thing, as simply that which is chosen or determined from the thing itself) - as Jonah was three days in the belly of the whale, so Christ was three days in the tomb. The second involves acts that are similar to Christ's: Typum facti appellant, cum factum unius est typus facti ab alio gesti vel gerendi" (they call it a type of a deed, when the act of the one is a type of the thing done by another, either already accomplished or being done) - as Samson crushed his enemies by his death, so too did Christ. The third is the most significant since it opens typology in general up to a variety of figurative significations: Typum Sac ramenti vocant, quando sub sensilibus res occultae, mysticae, \& futurae, tanquam sub typis \& figuris proponuntur" (they call it a type of the sacrament, when under carnal things hidden, mystical, and future things are set forth as types and figures) - as baptism is a type of the submersion of the old Adam and the emersion of the new man.

The fact that Keach omitted these two different systems of classification in favour of another indicates that no single terminology was widely adopted; however, the efforts to distinguish among kinds of types ought to indicate that the exegetes perceived types in a rather complex way. The reductive paradigm of promise and fulfillment (i.e., regarding all types as simple Christological ones) that modern scholars have used to describe them does not permit us to see the subtleties of these texts. In practice the popular typological guides like Guild's or Taylor's accepted many types that did not involve Christ as antitype, such as the ark as a type of Ecclesia, the crossing of the Red Sea as a type of baptism, and so forth. ${ }^{33}$ Though no broadly used terminology from this time survives, devising one helps us to understand and discuss the complex way typology - as a symbolic mode was used by seventeenth-century devotional poets.

Where medieval exegetes had generally limited the second level of scriptural interpretation (the allegorical or typological) to Christ's life and death as the antitype of Old Testament promissory events, Protestants eventually took the broader view that typology delineated the pattern of 
salvation for the individual in imitation of the pattern of Christ's life. In his first course of lectures on the Psalms (1513-1515), Luther, as Preus has demonstrated in his study of the emergence of Luther's reformation theology, changed his identification of the speaker in the Psalms from Christ himself (or the "prophet" speaking "in the person of the Church" or as "part of the Church") to those faithfully awaiting the advent of the Messiah, whose situation under the law, asking for Christ, paralleled that of the Christian in sin, asking forgiveness.$^{34}$ For the reformers and especially for the devotional poets who adopted them as models for their lyrics, the Psalms thereby became the spiritual record not only of Christ's sufferings, but typologically ofeach believer's as well. The difference between the "medieval" Luther at the beginning of his Psalms course and the "Protestant" Luther at the end marks the emergence of a distinctly Protestant view of the literal interpretation of the Old Testament (and hence the emergence of typology as a mode of analysis) as Preus argues:

In the later exegesis, by contrast, there is a communion of the whole people of God - the "communio sanctorum"- in their expectation and petition for Christ, and an accompanying tendency to broaden the Old Testament speaker to include, as it were, a "faithful remnant." While earlier the penitent was directed to identify himself with the vicariously penitent Christ, in word and in affectu (as in Psalm 37), later he is to identify himself with the petitioner of the "faithful synagogue" in his temptation and expectation (as in Psalm 142). ${ }^{35}$

Some modern historians have characterized the medieval view of the Old Testament as theologically empty, since only the advent of Christ gave it a spiritual meaning. ${ }^{36}$ Certainly, this overstates the case, for the medieval church had always made use of Old Testament exempla and history. Luther and other reformers, however, did seem to feel that they were restoring the proper theological significance to the Old Testament, since Israel before the advent existed under the same kind of promise as any believer did. The Israelites' faith in the covenant, in other words, made their history valuable. Perhaps it is only a matter of perspective, but it is clear that Protestants were sensitive to this issue for the Anglican church made it an article of faith (Article VI) that

The olde Testament is not to bee put awaie as though it were contrarie to the newe, but to be kept still: for bothe in the olde, and newe Testamentes, everlasting life is offred to mankinde by Christ, who is the onelie mediatour betweene Godde and manne, being bothe Godde and manne. Wherefore thei are not to be hearde, whiche feigne that the olde Fathers didde look onely for transitorie promises. ${ }^{37}$

In reestablishing the theological significance of the Old Testament, Luther was shifting emphasis away from the church and toward the individual's 
faith, toward scriptura sola as the foundation of Christianity. Correspondingly, the Bible - when read typologically - was understood to tell one story, Christ's, but through him the story of all the faithful. Lewalski has also remarked on the importance of the shift towards individualism made possible by the renewed interest in typology:

Though the Christian was traditionally understood to share in Christ's antitypical role of recapitulating and fulfilling Old Testament types forma perfectior, the locus of antitypical significance now tends to be primarily the individual Christian, who is said to recapitulate in himself the experiences recorded in both the Old and the New Testaments. ${ }^{38}$

Typological symbolism, then, became especially important for relating the individual Christian's life to Christ's in a crucial theological way.

In practice, few typologists confined their lists of types strictly to Christological ones, since typology as a symbolic mode seemed to unify Scripture as a whole. Sacramental participation (in its old sense of "mysterious") in Christ's life, the story of which is told through types, is obviously at the very heart of Christian hope. Though Protestants rejected the Roman Catholic belief in the efficacy of works, they certainly believed in the transcendent powers of grace. Salvation, for Luther and the reformers, was already won by Christ; it had only to be accepted in an act of faith (sola fides) or trust in the operation of God's free and unearned grace. The consequence of God's forgiveness, once man had made the act of faith, was sanctification, the inner regeneration effected by the Holy Spirit. ${ }^{39}$ Particularly in the Anglican church, the two biblically sanctioned sacraments were accepted as "certain sure witnesses and effectual signs of grace and God's goodwill towards us, by the which He doth work invisibly in us." 40 By the action of grace, the individual Christian could become Christ-like and hence could recapitulate Christological types. Thus while grace could not in any sense be "merited," its actions were clearly as important for Protestants as it had been for Catholics.

Even though Glass's distinction between typus facti and typus sacramenti seems not to have been widely adopted, he has given us a useful term with which to distinguish between Christological types and those in which the individual's sacramental participation in Christ's sacrifice is adumbrated. These can be properly called sacramental types. Most English typologists of the seventeenth century were clearly aware of the concept, for they spoke at great length of the "application" of the one typic sense of Scripture "to our instruction, faith, and manners." 11 In The Arte of Prophecying, for example, Perkins suggested that two kinds of application be made after Scripture was expounded: mental application to advance or refute doctrine and practical application to reform one's life. ${ }^{42}$ Similarly, in his exposition on one of the innate types sanctioned by Scripture, the rock of Horeb that 
follows the Israelites to sustain them in the desert, Thomas Taylor implicitly emphasized the significance of the type in both Christological and sacramental terms: "So the waters of grace streaming from the Rocke Jesus Christ, follow the beleeving Israel of God through the wildernesse of the world to the heavenly Canaan.... Where God begins with a man in sound and saving grace here, it will carry him into the land of promise. True grace must end in glory." 43 Taylor devoted about ten pages to explicating the rock as a type of Christ and about five pages to "applications" to help his readers avoid "Hardnesse of heart, which keepes the soule dry and barren" lest "all the waters of this spiritual rock are lost upon it," and so forth. ${ }^{44}$ In both meditations and sermons, Protestants insisted on a similar "application of the self" to the texts being meditated upon. ${ }^{45}$ Particularly for types of the biblically sanctioned sacraments, the typologists underscored the importance of the individual'smysterious participation in the fulfillment, typologically, of promises made possible through Christ. ${ }^{4 \dot{6}}$

In addition to the traditional Christological types and the sacramental types explained above, one other kind of type was implicitly recognized by seventeenth-century typologists. Their handbooks made frequent reference to what can be called the typology of the eschaton to describe the ultimate perfection of the events prefigured by both Christological and sacramental types that would occur in the fullness of time. If the type was but a shadow compared to the antitype, that light is weak compared to the blaze of glory with which the truth shall be illumined in the kingdom of glory:

Even now, in this marvellous light of the Gospell, we have our divine ceremonies and sacraments, see him afarre off, know but in part, darkly as in a glasse, and receive our best contentment by the acts of faith, while the Word and Spirit make us know the things freely given us of God in Christ Jesus. But time shall bee when (to say nothing of the estate of the Church after the ruine of Antichrist, and calling of the Jewes) we shall in heaven see him whom we beleeved, face to face, clearly, perfectly, immediately, without Sacraments or Types, in the fullest vision, nearest union, and absolutest fruition. ${ }^{47}$

Eschatological typology is a term that describes the ultimate fulfillment of God's promise in the New Jerusalem - to which even New Testament antitypes were merely shadows. This eschatological perfection would also be a recapitulation of Christ's perfection: "Christ's glorious transfiguration, was a forerunner of that glory that wee shall have in heaven: wee shall be made conformable to his glorious body, 1 Joh. 3.2."48 Milton, in a wellknown passage in De Doctrina Christiana, described the "incomplete glorification" that believers attain in this life and the "complete glorification" that would be attained in eternity. And Isaac Ambrose in his sermons on regeneration and the last things, Prima \& Ultima (1640), wrote: 
everie part and power of body and soule must have its part of sanctification, though no part his full perfection, before the dissolution of our earthly tabernacles: Hence (say Divines) there is a regeneration, or sanctification (it is all one) inchoata and consummata; inchoala, begun in this life, consummala, perfected in that other. ${ }^{49}$

Though other scholars describe the "application" of types differently notably Lewalski who prefers to describe them as "correlative" or recapitulative types - the terms Christological, sacramental, and eschatological correspond better with Glass's division of types (according to past, present, and future time) and to the complexities of the actual typological commentary, especially its eschatology. ${ }^{50}$ These terms also correspond to Luther's schema for the multiple exegesis of texts, which he based on the three advents of Christ - in the flesh, in the soul, and in the eschaton. ${ }^{51}$ We can easily make these distinctions consonant with Auerbach's terminology: if the type is the forma inferior and theantitype is the forma perfectior, in the eschaton the believers can look forward to the forma perfectissima.

The seventeenth-century practice of relying on three kinds of types in sermons and the like does bear some similarity to the medieval fourfold exegesis that discovered four distinct senses hidden in a text. Dante, for example, in his well-known letter to Can Grande della Scala explained that Psalm 114:1-2 described the departure of the children of Israel from Egypt (the literal sense), the redemption wrought by Christ (the allegorical sense), the conversion of the soul from grief (the moral sense), and the deliverance of the faithful to the New Jerusalem (the anagogical sense). ${ }^{52}$ While the reformers would have accepted Dante's explication of the text, they would have done so only because their commentary on the typology of the exodus could be confirmed by other textual evidence from the Bible. In theory, the reformers continued to reject the notion that Scripture has more than one sense. Generally they argued that the allegorical, tropological, and anagogical "are not properly divers senses but divers applications of one sense." ${ }^{3}$ By insisting that any additional level of meaning must be recovered as a dimension of the literal level of the text, the reformers were trying to avoid the mistakes of medieval exegetes, who had, they believed, erred in removing the sign from its literal, historical context. Once the text was freed from the interpretive constraints of its context, there seemed to be no way of governing how the texts could signify; and they attributed the excesses of patristic allegory to just such privatistic readings. In practice, however, the typologists of the seventeenth century were as capable of producing readings as imaginative as their patristic forebears (as the commentary on the tree of life, discussed below, illustrates). The complexities of the three kinds of types recognized implicitly by Protestant commentators ought to be a reminder of the continuity between medieval and 
Renaissance, even between Roman and reformed, spiritual practices. While the terms Christological, sacramental, and eschatological do not exactly correspond to the terminology of fourfold allegory and while the reformers' methodology was more firmly grounded in the literal text itself, the similarities reveal the common difficulties of recovering the riches of an intricate, demanding text.

Recognizing that such distinctions among kinds of types exist is necessary nonetheless, especially for students of literature, since it provides us with a vocabulary for describing the complexities of typological symbolism in the seventeenth century. For example, in the "Hymne to God my God, in my sicknesse," an occasional meditation on Donne's own deathwatch, the speaker perceives his personal drama in terms of the typological drama staged in Scripture. The complex typological symbolism of the fifth stanza is the figurative centre of the poem.

We think that Paradise and Calvarie,

Christs Crosse, and Adams tree, stood in one place;

Looke Lord, and find both Adams met in me;

As the first Adams sweat surrounds my face,

May the last Adams blood my soule embrace. ${ }^{54}$

One level of signification in this stanza obviously depends on the Christological typology that the biblical allusions pointedly establish: just as Adam is the forma futuri, "the figure of him that was to come" (Rom. 5:14), Christ is identified as the "last Adam" (I Cor. 15:45) who is the fulfillment of the Adamic type. And in the symmetrical minds of medieval commentators (and in Donne's own), the cross was erected on the spot where Adam was buried to highlight this typological correspondence. Christ as the fulfillment or antitype of Adam is patently a dimension of the poem's meaning. However, other typological dimensions exist that critics have difficulty discussing. For the speaker announces that he too plays a role in this same drama, as he finds "both Adams met in me." The typological symbolism suggests the speaker's own recapitulation of the mysteries of the fall, atonement, and salvation. He knows too well that the sweat of the first Adam lines his face - literally, the feverish sweat of his sickness, but figuratively the postlapsarian "sweat of thy face" (Gen. 3:19), the birthright of man and the speaker's true sickness. He prays that he too will be embraced by Christ, mystically commingling his sweat with the blood and sweat of Christ's own brow. The Christological fulfillment, that is, has made possible a sacramental recapitulation whereby the speaker can hope to be transformed into a Christ-like, second Adam himself. The image of the blood and sweat is also probably meant to suggest the blood and water flowing from the wound in Christ's side, the source of the sacraments and the "effectual sign" of grace. 
Yet another level of signification is involved through the allusion to Adam's tree. Though medieval legend identified the wood of the cross as either from the tree of life, from the tree of knowledge of good and evil, or from the tree of mercy (seedlings of which were planted at Adam's grave), no one has ascertained which tradition Donne is following. As Stanley Stewart shows, iconographic traditions linked the tree of life, the tree of knowledge, the apple tree of the Canticles, and the tree of Jesse; he calls them all types of a single, fruit-bearing tree, the ChristTree. ${ }^{55}$ The fact that Donne designates it a mbiguously as "Adams tree" probably ought to shift our attention away from any precise identification and toward the typological connection (which all the Christ-Trees would have shared): the tree which brought man death is fulfilled by the tree/cross which brings man life through death. This typological relationship may also be pointing ahead to the eschatological fulfillment of this type, the tree of life in the New Jerusalem that gives eternal life to the faithful (Rev. 22:2), especially in a poem whose speaker is contemplating his own death and looking ahead to his hoped-for glorification. Just such an understanding of the promise foreshadowed by the tree of life (in the flesh, in the soul, and eschatologically) can be found in popular handbooks on typology. William Guild began Moses Unvailed with the tree of life, and his three observations established that the tree of paradise has a Christological, a sacramental (through the church), and an eschatological antitype:

1. As it was called the Tree of life. So Christ is that true Tree of Life, giving the fruit \& juice both of grace and glory, Joh.15.1.

2. It was in the midst of the Garden. So Christ is to be found in the midst of his church, Mat.18.20.

3. It was in the earthly Paradise planted.

So Christ is in the heavenly placed, Mar.1619.56

Thus typology was used to link distinct but intersecting moments of time in the history and drama of Christ to foreshadow the typological drama of the believer and the whole span of sacred history; each of these moments, furthermore, was preparing for and moving toward one end. Put another way, there is one Christian faith - Christ mysteriously dead and risen - but this mystery is manifested in different ways: it is prefigured in the Old Testament and realized historically in the New; it is reenacted mysteriously through the sacraments; and it will be consummated eschatologically in the fulness of time. Donne himself offers clear evidence of this view of history in his Holy Sonnet "I am a little world made cunningly," which features the eschatological relationship between the flood and the apocalypse. In the new covenant made after the flood, God had promised never again to 
reduce the world to a watery, chaotic state; so, as a prefiguration of baptism, the flood had its eschatological fulfillment in the final regeneration by fire at the apocalypse. Since "black sin hath betrayed to endless night" the body and soul of Donne's speaker (1.3), he entreats astronomers and explorers to discover new sources of purifying water,

\section{that so I might}

Drowne my world with my weeping earnestly.

Or wash it if it must be drown'd no more.

But his own contrition is both insufficient and, finally, inadequate.

But oh it must be burnt; alas the fire
Of lust and envie have burnt it heretofore,
And made it fouler; Let their flames retire,
And burne me, o Lord, with a fiery zeale
Of thee and thy house, which doth in eating heale.

These lines connect the promise to regenerate the macrocosm by fire with the speaker's sacramental participation in the double baptism of fire and water. The typology of this sonnet thus links personal and sacred history together, revealing how one essential salvation drama is being played through the archetypal patterns of the Christian mythos. Readers of the Bible in the seventeenth century recovered these multiple levels of signification by collating text with text, image with image. To respect the complexity of the figuralism in seventeenth-century devotional poetry, we must therefore recognize the complex typological wit of such poets as Donne, Herbert, Vaughan, and Traherne.

\section{Texas $A \& M$ University}

Notes

1 William G. Madsen, From Shadowy Types to Truth: Studies in Milion's Symbolism (New Haven and London: Yale Univ. Press, 1968); Murray Roston, Biblical Drama in England from the Middle Ages to the Present Day (Evanston: Northwestern Univ. Press, 1968); Barbara K. Lewalski, "Samson Agonistes and the gTragedy" of the Apocalypse," PMLA, 85 (1970), 1050-61; Earl Miner, ed., Literary Uses of Typology from the Late Middle Ages to the Present (Princeton: Princeton Univ. Press, 1977); and Barbara K. Lewalski, Protestant Poetics and the Seventeenth-Century Religious Lyric (Princeton: Princeton Univ. Press, 1979).

2 Lewalski, Protestant Poetics, p. 117.

3 The locus classicus on typology in the context of English Protestantism is Lewalski's Protestant Poetics. The work of Jean Danielou remains helpful on patristic typology, especially The Bible and the Liturgy, no trans. given (Notre Dame, IN: Notre Dame Univ. Press, 1956) and From Shadows to Reality: Studies in the Biblical Typology of the Fathers, Wulstan Hibberd, trans. (London: Burns \& Oates, 1960). On the literary application of typology, see Paul J. Korshin, Typologies in England, 1650-1820(Princeton: Princeton Univ. Press, 1982); Ira Clark, Christ Revealed: The History of the Neotypological Lyric in the English Renaissance, Univ. of Florida Monographs, Humanities No. 51 (Gainesville, FL: Univ. Presses of Florida, 1982); Mason I. Lowance, Jr., 


\section{0 / Renaissance and Reformation}

The Language of Canaan (Cambridge, MA: Harvard Univ. Press, 1980); Miner's Literary Uses of Typology; and Joseph A. Galdon, Typology and Seventeenth-Century Literature (The Hague: Mouton, 1975). General studies on typology include Erich Auerbach, "Figura," in Scenes from the Drama of European Literature, Ralph Manheim, trans. (New York: Meridian, 1959), pp. 1176; Victor Harris, "Allegory to Analogy in the Interpretation of Scriptures During the Middle Ages and the Renaissance," PQ, 45 (1966), 1-23; and John R. Mulder, The Temple of the Mind (New York: Pegasus, 1969), pp. 130-50. For a general bibliography on typology, see Sacvan Bercovitch, ed., Typology and Early American Literature (Amherst: Univ. of Massachusetts Press, 1972), pp. 245-337.

4 John Smith, The Mysterie of Rhetorique Unveil'd (London, 1657), sig. a5v.

5 William Perkins, The Arte of Prophecying, Thomas Tuke, trans., in The Works of that famous and worthie Minister of Christ, 3 vols. (London, 1616-1618), II, 651.

6 Henry Lukin, An Introduction to the Holy Scriptures (London, 1669), p. 34.

7 Lukin, p. 34.

8 Perkins, II, 651-52, wrote: "The analogie of faith, is a certaine abridgement or summe of the Scriptures, collected out of most manifest \& familiar places. The parts thereof are two. The firstconcerneth faith, which is handled in the Apostles 'Creede. The second concerneth charity or love, which is explicated in the tenne Commandements." See also John White, $A$ Way to the Tree of Life: Discovered in Sundry Directions for the Profitable Reading of the Scriptures (London, 1647), pp. 166-67, and Lukin, p. 33.

9 White, pp. 160-69; Perkins, II, 650-54; and Lukin, pp. 32-37.

10 John Weemes, The Christian Synagogue, 4th ed. (London, 1633), pp. $42-84$.

11 Perkins, II, 652.

12 Weemes, Christian Synagogue, pp. 58-59.

13 Weemes, Christian Synagogue, p. 60.

14 Auerbach, pp. 50-51.

15 For a brief account of the typology of the Fathers, see Danielou, From Shadows to Reality.

16 James Samuel Preus, From Shadow to Promise: Old Testament Interpretation from Augustine to the Young Luther (Cambrige, MA: Belknap, 1969), pp. 50-51; and Lewalski, Protestant Poetics, pp. 114-16, for an account of medieval sign theory. For a precis of current theories, see Terence Hawkes, Structuralism and Serniotics (Berkeley and Los Angeles: Univ. of California Press, 1977).

17 St. Thomas Aquinas, Summa Theologiae, Thomas Gilby et al., trans. and ed., 60 vols. (New York: McGraw-Hill; London: Eyre \& Spottiswoode, 1964), I.a.10 (I, 37, 39).

18 Harry A. Wolfson, The Philosophy of the Church Fathers, Vol. 1: Faith, Trinity, Incarnation, 2nd ed. (Cambridge, MA: Harvard Univ. Press, 1956), p. 31.

19 Preus, pp. 200-11.

20 Lukin, p. 124.

21 Weemes, Christian Synagogue, p. 230. See also White, p. 167.

22 On Calvin, see Lewalski, Protestant Poetics, pp. 118-19; on Erasmus, see David Quint, Origin and Originality in Renaissance Literature: Versions of the Source (New Haven and London: Yale Univ. Press, 1983), pp. 17-21.

23 Weemes, Christian Synagogue, explained: "God hath so tempered the Scriptures, that hee hath not onely expressed his will in words, but also in matter, in types and figures. There is an Allegory in words, and an Allegorie in matter; in words, Metaphors; in matter, Types; in Figures, the Antecedent signifies the thing consequent; \& the literall sense is fulfilled before the mysticall sense" (pp. 23233).

24 Weemes, Christian Synagogue, wrote: "The nature of a Metaphor, is to proceed from sensible things to spirituall, and not contrarily" (p. 244).

25 Benjamin Keach, Tropologia: A Key to Open Scripture Metaphors, 3 pts. (London, 1682), I, sig. A3v, wrote: "Types are only Historical, as such; and the Truth of Fact agreeing in the Antitype 
makes them up." Auerbach, "Figura," pp. 49-60, discusses this at length.

26 Thomas Taylor, Christ Revealed; or, The Old Testament explained (London, 1635), pp. 2-3. The usual metaphor was shadow before the light, and the type was often called umbra or imago. William Guild, Moses Unvailed; or, those figures which served untothe patterne and shaddow of heavenly things, 2nd ed. (London, 1623), sig. A3r-v, stated: "As in the Creation darknes went before the light, or as the dawning precedes the brightnesse of the day... Even so... darke shaddowes were the fore-runners of that bright substance, obscure types were harbingers to that glorious Anti-type the Messiah, who was coming after."

27 Tropologia contains three parts: Part I, entitled "Sacred Philology," was taken largely from Liber V of Glass ("Rhetorica sacra"); Parts II and III, entitled "Practical Improvement of ... Metaphors, Allegories, and express Similitudes," listed numerous examples of the figurative language of the Bible. The last parts were published separately as Troposchemalogia: Tropes and Figures (London, 1682), which was further identified on the title page as "Philologia Sacra, the Second Part ... together with a treatise of Types." This little treatise was a direct translation of part of Glass's Liber II. The second edition of Tropologia (London, 1779) gathers all these parts together and continuously paginates them (though "Philologia sacra" is inserted after Part I).

28 Keach, Troposchemologia, II, 41-45 (sic).

29 Though Clark, pp. 12-17, cites William Whitaker, Disputatio de Sacra Scriptura contra huiustemporis Papistas (Cambridge, 1588), among others to show that some did limit types to those specifically mentioned in the Bible, many of the popularizers of typology published thick guides that listed non-scripturally sanctioned types. Samuel Lee's Orbis miraculum; or, The Temple of Solomon (London, 1659), a work Clark cites as favouring scripturally sanctioned types, was in fact less literal minded than Clark indicates. While Lee argued that types can only be deduced by Scripture, he did not insist that the antitype specify its type unequivocally. The injunction Lee offered was to ascribe to nothing "but to such as Holy Scripture doth either directly, or by strong and clear consequence hand forth to us" (p. 170). As long as an argument for a particular typological relationship is grounded in the text itself, Lee allowed the interpreter certain liberties. Indeed it is useful to recall that the Orbis miraculum devoted over three hundred folio pages to explicating the typology of Solomon's temple.

30 Keach, Troposchemalogia, II, 31-32.

31 Keach, Troposchemalogia, II, 28-32.

32 Salomon Glass, Philologiae Sacrae ... libri quinque, 2nd ed., 3 vols. in 1 (Jena 1636-1645), I, 45053. Junilius, De partibus Divinae Legis libri II, was evidently well regarded by the reformers. Glass quoted him and another major writer on the figurative language of Scripture, Matthias Flacius Illyricus, reproduced the entire second book of De partibus Divinae Legis in the section on typology in his own Clavis Scripturae Sacrae; seu de sermone sacrarum literarum, 2 vols. (Jena, 1567).

33 Lukin, p. 114, defined types broadly as "such things as were in the Old Testament intended by the Holy Ghost to signifie, and prefigure Jesus Christ, or something belonging to his Spiritual Kingdom: and that which answers thereto, we commonly call the Antitype."34 Preus, pp. 15375.

35 Preus, p. 174.

36 Preus, p. 163, uses this phrase.

37 Edgar C. S. Gibson, The Thirty-Nine Articles of the Church of England, 2nd ed. (London: Methuen, 1898), p. 72.

38 Barbara K. Lewalski, Donne's Anniversaries and the Poetry of Praise (Princeton: Princeton Univ. Press, 1973), pp. 160-61.

39 Horton Davies, Worship and Theology in England from Cranmer to Hooker, 1534-1603 (Princeton: Princeton Univ. Press, 1970), pp. 17-25.

40 Gibson, p. 585.

41 Weemes, Christian Synagogue, p. 234. Moreover, he used this notion to explain how the "Papists" had gone astray with their fourfold interpretation, since the allegorical, tropological 


\section{2 / Renaissance and Reformation}

and anagogical "are not properly divers senses but divers applications of one sense to our instruction, faith, and manners" (p. 234).

42 Perkins, II, 668-69.

43 Taylor, p. 295.

44 Taylor, p. 301.

46 Lewalski, Donne's Anniversaries, pp. 73-107, discusses the similarities between Protestant sermons and meditations.

46 Taylor devoted considerable attention towards explaining how Jewish ritual prefigured the New Testament sacraments, which themselves have become the "witnesse and signe" of the new covenant (pp. 203-05). See also, Davies, pp. 32-34, 62-64.

47 William Jemmat, "Epistle Dedicatory" to Taylor's Christ Revealed, sig, A2v. See also, Guild, p. 76, and Lukin, p. 117.

48 John Weemes, The Portraiture of the Image of God in Man in His Three Estates, of Creation. Restauration. Glorification, 2nd ed. (London, 1632), pp. 38-39.

49 John Milton, Christian Doctrine, John Carey, trans., Maurice Kelley, ed., vol. VI of The Complete Prose Works of John Milton (New Haven: Yale Univ. Press, 1973), pp. 502, 614. Isaac Ambrose, Prima \& ultima: The First \& Last Thinges; or, Regeneration and Meditation Sermons (London, 1640), pp. 10-11.

50 See Lewalski's PMLA article on "Samson Agonistes and the 'Tragedy" of the Apocalypse." Danielou, The Bible and the Liturgy, pp. 5-6, and Shadows, p. 277, also distinguishes among Christological, sacramental, and eschatological types to explain the complex traditions behind the liturgy (though he does not use them systematically as I attempt to do).

51 See Preus, pp. 192-99.

52 Charles S. Singleton, Dante's Commedia: Elements of Structure, Dante Studies, No. 1 (Baltimore and London: The John Hopkins Univ. Press, 1954), pp. 84-90.

53 Weemes, Christian Synagogue, p. 234.

54 The Complete Poetry of John Donne, John T. Shawcross, ed. (Garden City, NY: Anchor, 1967), p. 391. Lewalski also recognizes the typological foundation of these lines, Protestant Poetics, pp. 280-82.

55 Stanley Stewart, The Enclosed Garden: The Tradition and the Image in Seventeenth-Century Poetry (Madison: Univ. of WisconsinPress, 1966), pp. 75-86. Similarly, David Pareus, In Genesin Mosis commentarius (Geneva, 1614), cols. 321-22, called the tree of life a sacrament which symbolized the admonishments man had accepted of God; it also symbolized man's heavenly reward; finally it symbolized Christ in whom Adam and all men are recuperated. See also, D. C. Allen, "John Donne's 'Paradise and Calvarie," MLN, 60 (1945), 398-400; John Donne, The Divine Poems, Helen Gardner, ed., 2nd ed. (Oxford: Clarendon, 1978), pp. 135-37; and Donald K. Anderson, Jr., "Donne's 'Hymne to God my God, in my sicknesse' and the T-in-O Maps," $S A Q$, 71 (1972), 465-72.

56 Guild, p. 1. 